\title{
Activation of the IGF Axis in Thyroid Cancer: Implications for Tumorigenesis and Treatment
}

\author{
Livia Manzella ${ }^{1,2, *, \dagger}$, Michele Massimino ${ }^{1,2, \dagger}$, Stefania Stella ${ }^{1,2, \dagger}$, Elena Tirrò ${ }^{1,2} \mathbb{D}$, \\ Maria Stella Pennisi 1,2, Federica Martorana 2,3(D), Gianmarco Motta 2,3, Silvia Rita Vitale 1,2, \\ Adriana Puma 1,2, Chiara Romano 1,2, Sandra Di Gregorio 1,2, Marco Russo ${ }^{4}$, \\ Pasqualino Malandrino 4 (D) and Paolo Vigneri ${ }^{1,2}$ \\ 1 Department of Clinical and Experimental Medicine, University of Catania, 95123 Catania, Italy \\ 2 Center of Experimental Oncology and Hematology, A.O.U. Policlinico-Vittorio Emanuele, \\ 95123 Catania, Italy \\ 3 Department of Medical Oncology A.O.U. Policlinico-Vittorio Emanuele, 95123 Catania, Italy \\ 4 Endocrinology, Department of Clinical and Experimental Medicine, Garibaldi-Nesima Medical Center, \\ University of Catania, 95122, Italy \\ * Correspondence: manzella@unict.it; Tel.: +39-095-3781970 \\ + These authors contributed equally to this work.
}

Received: 13 June 2019; Accepted: 28 June 2019; Published: 2 July 2019

check for updates

\begin{abstract}
The Insulin-like growth factor (IGF) axis is one of the best-established drivers of thyroid transformation, as thyroid cancer cells overexpress both IGF ligands and their receptors. Thyroid neoplasms encompass distinct clinical and biological entities as differentiated thyroid carcinomas (DTC)—comprising papillary (PTC) and follicular (FTC) tumors—respond to radioiodine therapy, while undifferentiated tumors-including poorly-differentiated (PDTC) or anaplastic thyroid carcinomas (ATCs) - are refractory to radioactive iodine and exhibit limited responses to chemotherapy. Thus, safe and effective treatments for the latter aggressive thyroid tumors are urgently needed. Despite a strong preclinical rationale for targeting the IGF axis in thyroid cancer, the results of the available clinical studies have been disappointing, possibly because of the crosstalk between IGF signaling and other pathways that may result in resistance to targeted agents aimed against individual components of these complex signaling networks. Based on these observations, the combinations between IGF-signaling inhibitors and other anti-tumor drugs, such as DNA damaging agents or kinase inhibitors, may represent a promising therapeutic strategy for undifferentiated thyroid carcinomas. In this review, we discuss the role of the IGF axis in thyroid tumorigenesis and also provide an update on the current knowledge of IGF-targeted combination therapies for thyroid cancer.
\end{abstract}

Keywords: IGF axis; thyroid cancer; therapeutic approach

\section{Introduction}

Insulin-like growth factor (IGF) signaling promotes cell proliferation and differentiation in normal human tissues [1,2].

The IGF system comprises the IGF ligands 1 (IGF-1) and 2 (IGF-2) which modulate multiple biological processes by interacting with specific cell-surface receptors represented by IGF receptors I and II (IGF-IR and IGF-IIR) [3-6]. IGF binding to IGF receptors is mediated by soluble IGF binding proteins (IGFBPs), a family of six homologous molecules (IGFBP-1-6) with high binding affinity for IGF-1 and IGF-2 [2,7].

IGF-IR and IGF-IIR (IGFRs) show different structures and function. In detail, IGF-IR is a member of the receptor tyrosine kinases (RTK) and binds IGF-1 with a higher affinity than IGF-2. IGF-IR forms 
a tetrameric complex consisting of two alpha and two beta subunits linked by disulfide bonds through fibronectin type III (FnIII) domains. The alpha subunit localizes in the extracellular space and consists of two large homologous regions (L1 and L2) separated by a cysteine rich domain responsible for ligand binding. The beta subunit displays a trans-membrane segment and an intracellular portion containing the tyrosine kinase domain (TKD) that actively phosphorylates direct downstream targets on selected tyrosine residues [6]. Unlike IGF-IR, IGF-IIR lacks catalytic activity presenting instead a monomeric structure consisting of a large extracellular portion of 15 contiguous domains followed by a short trans-membrane region. Hence, IGF-IIR shows scavenger properties towards circulating IGF-2 [6,8].

An additional feature of the IGF axis is its crosstalk with insulin and insulin receptors isoforms A (IR-A) and B (IR-B). Indeed, the IGF system contributes to thyroid cancerogenesis via an IGF-2/IR-A autocrine loop as IGF-2 activates the IR-A isoform over-expressed in neoplastic thyrocytes, thus promoting their proliferation and suppressing apoptosis $[9,10]$. However, IR-A, IR-B and IGF-IR generate hybrid tetramers (IGF-IR/IR-A) (IGF-IR/IR-B), which bind both IGF-1/-2 and insulin. Upon ligand binding, these hybrid receptors promote cell proliferation and cell adhesion but inhibit programmed cell death [11-13].

To date, several studies have established that aberrant IGF signaling plays a critical role in cancer pathogenesis and progression. Increased expression of IGF ligands and receptors has been observed in tumors of the breast, lung, pancreas, colon, prostate, ovary, and thyroid and is usually associated with a poor prognosis $[1,6,14,15]$.

Thyroid cancer is a frequently encountered endocrine malignancy sometimes aided by exposure to multiple environmental carcinogens favoring the generation of different molecular alterations [16-20]. Thyroid cancer mostly originates from the follicular epithelium and comprises differentiated (DTC), poorly differentiated (PDTC) and anaplastic (ATC) tumor histotypes. While DTCs are typically characterized by a favorable prognosis, PDTCs and ATCs have an unfavorable clinical course and are usually unresponsive to radioactive iodine because of their lack of the sodium iodide symporter (NIS) [21]. Finally, approximately $3 \%$ of all thyroid tumors are medullary thyroid carcinomas (MTC) deriving from the neoplastic transformation of neuroendocrine C-cells [21,22].

As the IGF system has been actively investigated in thyroid cancer $[9,10,14,23]$, in this review, we will provide an update focusing on the role of the IGF axis in thyroid cancer development and treatment.

\section{IGF Signaling in Thyroid Cancer}

Deregulation of the IGF axis is emerging as a key factor promoting proliferative responses in both normal and neoplastic thyrocytes [1,10,24,25]. Indeed, while both IGF-1 and IGF-IR are expressed in benign and malignant thyroid tissues [26], Belfiore and colleagues reported that IGF-IR is more expressed in DTCs, allowing IGF-1 to exert a potent mitogenic effect [27]. These data are in agreement with an additional manuscript describing a positive correlation between serum IGF-1 levels and the risk of developing DTCs [28].

Since the IGF cascade relies on IGFBP-mediated interactions between the IGF ligands and IGF-IR, several studies have investigated if IGFBPs are involved in thyroid tumorigenesis [29,30]. Indeed, experimental data suggest that IGFBPs sequester circulating IGF-1 and IGF-2, thus limiting their IGF-IR interaction and exerting a tumor suppressor activity [1,31]. Hence, IGFBP-1 overexpression attenuates IGF-1 activity, at least in vitro [32].

Signaling downstream of the IGF axis involves intracellular mediators contributing to cell proliferation Rat Sarcoma (RAS)/Proto-Oncogene Serine/Threonine-Protein Kinase (RAF)/Mitogen-Activated Protein Kinase inhibitors (MEK)/Extracellular Signal-Regulated Kinase (ERK), apoptosis inhibition, protein synthesis, cell cycle progression Phosphatidylinositol kinase (PI3K)/V-Akt Murine Thymoma Viral Oncogene Homolog (AKT)/Mammalian Target of Rapamycin (mTOR) and cell motility Focal Adhesion Kinase (FAK) [33-35]. Activation of the IGF-IR receptor by IGF ligands leads to its tyrosine 
phosphorylation thus generating a binding site for docking proteins such as Src Homology 2 Domain Containing Transforming Protein 1 (SHC) and Insulin receptor substrates (IRSs). In turn, SHC recruitment activates RAS/RAF/ERK pathway while IRS1 and IRS2 activate the PI3K/AKT/mTOR and FAK cascades, respectively (Figure 1) [36-38].

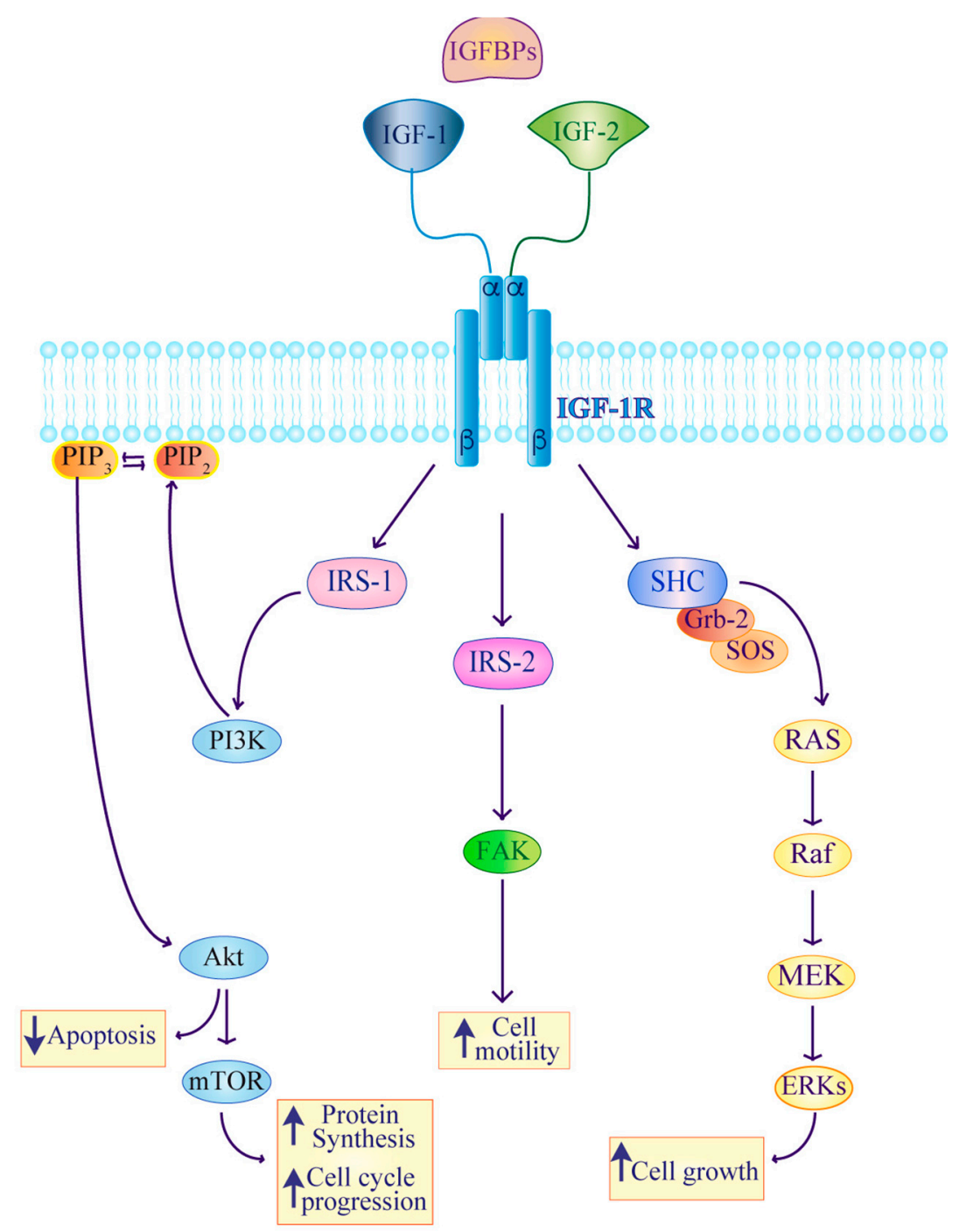

Figure 1. Schematic representation of the IGF-IR downstream signaling. Activation of IGF-IR is triggered by IGF1/2 ligands and modulated by IGFBPs. After ligand binding, IGF-IR recruits docking proteins including IRSs and SHC which induce the activation of intracellular modulators involved in: cell growth (RAS/RAF/MEK/ERK), protein synthesis, cell cycle progression (PI3K/AKT/mTOR) and cell motility [33]. Activated IGF-IR also inhibits apoptosis.

The involvement of the IGF axis in thyroid carcinoma is also related to crosstalk interactions between the IGF-IR and thyroid-stimulating hormone (TSH). In fact, the pro-tumorigenic effect of TSH is reduced in the absence of growth factors, but is increased by IGF-1 stimulation $[10,39,40]$. Moreover, Sarah and colleagues reported that the crosstalk between TSH and the IGF-IR through ERK and AKT pathways up-regulates NIS expression in primary tumor thyrocytes [41]. Additional data by Fukushima and colleagues indicate that cAMP-stimulating agents such as TSH induce a Nedd4-dependent ubiquitination of IRS-2 that, when associated with Nedd4, enhances IGF-dependent mitogenic effects (Figure 2) [42]. 


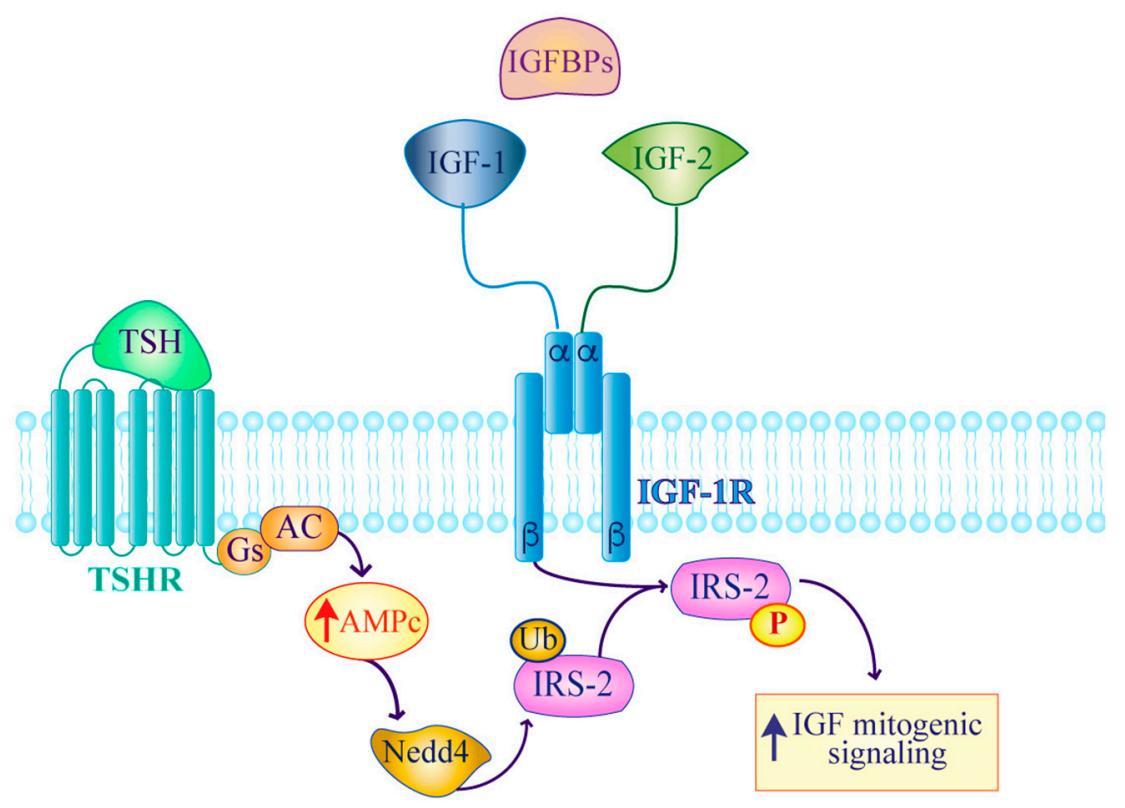

Figure 2. Working model depicting how the TSH/Nedd4/IRS2 axis improves IGF mitogenic activity. cAMP-stimulating agents such as TSH, promote Nedd4-dependent ubiquitination of IRS-2 thereby assembling a Nedd4-IRS-2 complex that enhances IGF-dependent mitogenic signaling. AC: Adenylyl cyclase; Gs: G Protein.

An additional layer of complexity to this already composite signaling network is represented by the well documented crosstalk between the IGF axis and several RTKs including the insulin receptor (IR), epidermal growth factor receptor (EGFR), vascular endothelial growth factor receptor (VEGFR), platelet-derived growth factor receptor (PDGFR), hepatocyte growth factor receptor (HGFR-proto-oncogene MET), the discoidin domain receptor tyrosine kinase 1 (DDR1) and the anaplastic lymphoma kinase 1 (ALK) [43-47]. The cooperation between the IGF-IR and other RTKs activate common downstream targets such as the PI3K/AKT/mTOR and RAF/MEK/ERK pathways, thus promoting tumor proliferation and inhibiting apoptosis. Moreover, although deregulation of the IGF pathway is linked to aberrant activation of the IGFRs, several mutations of its downstream targets or additional gene rearrangements may also indirectly activate the IGF axis. Obviously, these molecular events represent a potential resistance mechanism to IGF ligand/receptor inhibitors [12,48-51].

\section{Targeting IGF Signaling in Thyroid Cancer}

Therapeutic approaches targeting the IGF axis have been investigated in many cancers as consistent evidence suggests that IGF signaling confers resistance to several anti-tumor agents [19,52-55]. On the basis of these observations, IGF axis inhibitors have been combined with DNA damaging agents or different kinase inhibitors [43,56-60]. In this section, we provide an update on the current knowledge of agents that directly (IGF-IR direct inhibitors) or indirectly (IGF-IR/RTKs downstream inhibitors) interfere with the IGF axis in thyroid carcinoma (Figure 3). Specifically, we focus on findings generated in immortalized cell lines, mouse models or in clinical trials. All published or ongoing clinical trials are reported in Tables 1 and 2. 


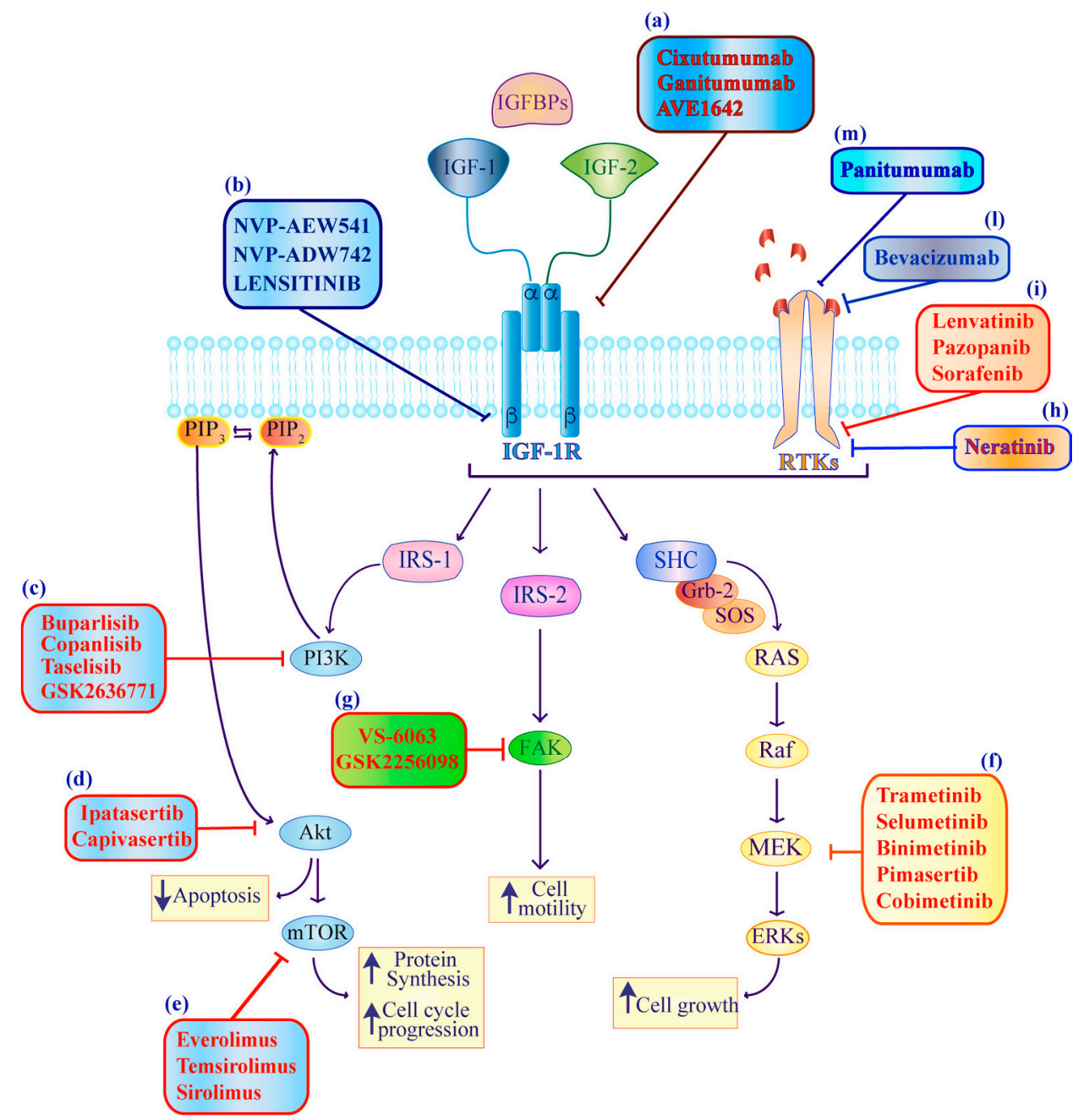

Figure 3. Schematic representation of direct and indirect pharmacological agents targeting the IGF axis that have been investigated in thyroid cancer. IGF-IR direct inhibitors, IGF-IR ${ }^{\mathrm{mAbs}}(\mathbf{a})$ and IGF-IR ${ }^{\mathrm{TKIs}}(\mathbf{b})$ reduce IGF downstream signaling. IGF-IR/RTK downstream inhibitors targeting PI3K (c), AKT (d) and mTOR (e) restore apoptosis while blocking protein synthesis and cell cycle progression. MEK (f) and FAK (g) inhibitors interfere with cell motility, respectively, while EGFR inhibitors (h), MK (multi-kinase) inhibitors (i) and $\mathrm{RTK}^{\mathrm{mAbs}}(\mathbf{m})$ hinder the cooperation between the IGF-IR and other RTKs. 
Table 1. Clinical studies with published data.

\begin{tabular}{|c|c|c|c|c|c|c|}
\hline Class of Drugs & Drug Name & Published Data & Phase & Tumor Type & $\mathbf{N}^{\circ *}$ & Regimen \\
\hline \multirow{3}{*}{ IGF-IRi } & AVE1642 & [61] & I & Advanced Solid & 1 & AVE1642+Docetaxel \\
\hline & Cixutumumab & [62] & I & Advanced Solid & 4 & Cixutumumab + Selumetinib \\
\hline & Ganitumab & [63] & I & Advanced Solid & 2 & Ganitumab + Sorafenib or Panitumumab \\
\hline \multirow{2}{*}{ PI3Ki } & \multirow{2}{*}{ Buparlisib } & [64] & I & Advanced Solid & 1 & Monotherapy \\
\hline & & [65] & II & FTC + PDTC & 43 & Monotherapy \\
\hline AKTi & Ipatasertib & [66] & I & Advanced Solid & 1 & Monotherapy \\
\hline \multirow{2}{*}{ FAKi } & VS-6063 & [67] & I & Advanced Solid & 1 & Monotherapy \\
\hline & GSK2256098 & [68] & I & Advanced Solid & 2 & Monotherapy \\
\hline \multirow{6}{*}{ MEKi } & Binimetinib & [69] & II & Advanced Solid & 2 & Monotherapy \\
\hline & Pimasertib & [70] & I & Advanced Solid & 1 & Pimasertib+Temsirolimus \\
\hline & \multirow{2}{*}{ Selumetinib } & [71] & I & Advanced Solid & 2 & Selumetinib + Temsirolimus \\
\hline & & [72] & I & PTC & 39 & Monotherapy \\
\hline & \multirow{2}{*}{ Trametinib } & [73] & I & Advanced Solid & 5 & Monotherapy \\
\hline & & [74] & I & Advanced Solid & 1 & Trametinib + Everolimus \\
\hline \multirow{8}{*}{ mToRi } & \multirow{6}{*}{ Everolimus } & [75] & II & ATC & 5 & Monotherapy \\
\hline & & [76] & I & Advanced Solid & 7 & Everolimus + Cisplatin \\
\hline & & [77] & II & $\mathrm{DTC}+\mathrm{ATC}+\mathrm{MTC}$ & 40 & Monotherapy \\
\hline & & [78] & II & MTC & 7 & Monotherapy \\
\hline & & [79] & II & DTC + MTC & 41 & Everolimus + Sorafenib \\
\hline & & [80] & II & $\mathrm{DTC}+\mathrm{ATC}$ & 28 & Monotherapy \\
\hline & \multirow{2}{*}{ Temsirolimus } & [81] & I & Advanced Solid & 1 & Temsirolimus + Trebananib \\
\hline & & [79] & II & $\mathrm{DTC}+\mathrm{ATC}$ & 36 & Temsirolimus + Sorafenib \\
\hline
\end{tabular}

$\mathrm{N}^{\circ *}$ of thyroid cancer patients in each trial; FTC Follicular Thyroid Cancer; PDTC Poorly Differentiated Thyroid Cancer, MTC Medullary Thyroid Cancer, DTC Differentiated Thyroid Cancer, ATC Anaplastic Thyroid Cancer. 
Table 2. Ongoing or completed yet unpublished clinical trials.

\begin{tabular}{|c|c|c|c|c|c|c|}
\hline Intervention & Population & Design & Pts (n) & Primary End Point & Status & Identifier \\
\hline 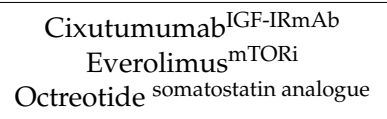 & $\begin{array}{l}\text { Advanced low- or intermediate-grade } \\
\text { neuroendocrine cancers }\end{array}$ & $\begin{array}{l}\text { Nonrandomized, } \\
\text { Open label, phase I }\end{array}$ & $\begin{array}{c}27 \\
\text { actual }\end{array}$ & DLTs, PD, PK, SP & Completed & NCT01204476 \\
\hline $\begin{array}{c}\text { Binimetinib }{ }^{\text {MEKi }} \\
\text { Capivasertib }^{\text {Akt }} \\
\text { Copanlisib }^{\text {PI3Ki }} \\
\text { Taselisib }{ }^{\text {II3Ki }} \\
\text { GSK2636771 } \\
\text { Trametini }^{\text {MEKi }} \\
\end{array}$ & $\begin{array}{l}\text { Genetic testing-directed targeted } \\
\text { therapy in patients with advanced } \\
\text { refractory solid tumors, lymphomas, or } \\
\text { multiple myeloma }\end{array}$ & $\begin{array}{l}\text { Nonrandomized, } \\
\text { Open label, phase II } \\
\text { (molecular analysis } \\
\text { for therapy choice) }\end{array}$ & $\begin{array}{c}6452 \\
\text { estimated }\end{array}$ & ORR & Recruiting & NCT02465060 \\
\hline $\begin{array}{l}\text { Everolimus mTORi } \\
\text { Sorafenib MKi }\end{array}$ & $\begin{array}{l}\text { Metastatic differentiated thyroid cancer } \\
\text { progressed on Sorafenib }\end{array}$ & $\begin{array}{l}\text { Nonrandomized, } \\
\text { Open label, phase II }\end{array}$ & $\begin{array}{c}40 \\
\text { estimated } \\
\end{array}$ & ORR, PFS & Active, not Recruiting & NCT01263951 \\
\hline $\begin{array}{l}\text { Everolimus }{ }^{\text {mTORi }} \\
\text { Sorafenib }^{\text {MKi }}\end{array}$ & $\begin{array}{l}\text { Advanced thyroid cancer naive to } \\
\text { m-TOR inhibitors or Sorafenib }\end{array}$ & $\begin{array}{l}\text { Nonrandomized, } \\
\text { Open label, phase II }\end{array}$ & $\begin{array}{c}41 \\
\text { actual }\end{array}$ & ORR & Active, not Recruiting & NCT01141309 \\
\hline $\begin{array}{c}\text { Everolimus mTORi } \\
\text { Pasireotide } \\
\text { somatostatin analogue }\end{array}$ & $\begin{array}{l}\text { Radioiodine-refractory differentiated } \\
\text { and medullary thyroid cancer }\end{array}$ & $\begin{array}{c}\text { Randomized, } \\
\text { Open label, phase II }\end{array}$ & $\begin{array}{c}42 \\
\text { actual }\end{array}$ & ORR & Completed & NCT01270321 \\
\hline Everolimus mTORi & Radioiodine-refractory thyroid cancer & $\begin{array}{l}\text { Nonrandomized, } \\
\text { Open label, phase II }\end{array}$ & $\begin{array}{c}33 \\
\text { estimated }\end{array}$ & PFS & Active, not Recruiting & NCT00936858 \\
\hline $\begin{array}{l}\text { Everolimus mTORi } \\
\text { Sorafenib }^{\text {MKi }}\end{array}$ & $\begin{array}{l}\text { Advanced radioiodine-refractory } \\
\text { Hurthle cell thyroid cancer }\end{array}$ & $\begin{array}{c}\text { Randomized, } \\
\text { Open label, phase II }\end{array}$ & $\begin{array}{c}34 \\
\text { estimated }\end{array}$ & PFS & Recruiting & NCT02143726 \\
\hline $\begin{array}{l}\text { Everolimus mTORi } \\
\text { Lenvatinib MKi }\end{array}$ & $\begin{array}{l}\text { Metastatic differentiated thyroid cancer } \\
\text { progressed on Lenvatinib }\end{array}$ & $\begin{array}{l}\text { Nonrandomized, } \\
\text { Open label, phase II }\end{array}$ & $\begin{array}{c}40 \\
\text { estimated } \\
\end{array}$ & PFS & Recruiting & NCT03139747 \\
\hline $\begin{array}{c}\text { Everolimus mTORi } \\
\text { Pasireotide somatostatin analogue }\end{array}$ & Advanced medullary thyroid cancer & $\begin{array}{l}\text { Nonrandomized, } \\
\text { Open label, phase II }\end{array}$ & $\begin{array}{c}19 \\
\text { actual }\end{array}$ & PFS & Completed & NCT01625520 \\
\hline Everolimus mTORi & $\begin{array}{l}\text { Locally advanced or metastatic thyroid } \\
\text { cancer }\end{array}$ & $\begin{array}{l}\text { Nonrandomized, } \\
\text { Open label, phase II }\end{array}$ & $\begin{array}{c}40 \\
\text { actual }\end{array}$ & ORR & Completed & NCT01164176 \\
\hline $\begin{array}{c}\text { Everolimus mTORi } \\
\text { Neratinib EGFRi } \\
\text { or } \\
\text { Neratinib EGFRi } \\
\text { Trametinib MEKi }\end{array}$ & $\begin{array}{c}\text { Advanced cancer with EGFR } \\
\text { mutation/amplification, } H E R 2 \\
\text { mutation/amplification, } H E R 3 / 4 \\
\text { mutation or KRAS mutation }\end{array}$ & $\begin{array}{l}\text { Nonrandomized, } \\
\text { Open label, phase I }\end{array}$ & $\begin{array}{c}120 \\
\text { estimated }\end{array}$ & DLTs & Recruiting & NCT03065387 \\
\hline $\begin{array}{l}\text { Everolimus mTORi } \\
\text { Vatalanib VEGFi }^{\text {VEG }}\end{array}$ & Advanced solid tumors & $\begin{array}{l}\text { Nonrandomized, } \\
\text { Open label, phase I }\end{array}$ & $\begin{array}{c}96 \\
\text { estimated }\end{array}$ & DLTs, SP & Completed & NCT00655655 \\
\hline
\end{tabular}


Table 2. Cont.

\begin{tabular}{|c|c|c|c|c|c|c|}
\hline Intervention & Population & Design & Pts (n) & Primary End Point & Status & Identifier \\
\hline $\begin{array}{l}\text { Bevacizumab }{ }^{\text {VEGFmAbs }} \\
\text { Temsirolimus }\end{array}$ & $\begin{array}{l}\text { Advanced or metastatic malignancies or } \\
\text { other benign diseases }\end{array}$ & $\begin{array}{l}\text { Nonrandomized, } \\
\text { Open label, phase I }\end{array}$ & $\begin{array}{c}216 \\
\text { estimated } \\
\end{array}$ & DLTs & Recruiting & NCT01552434 \\
\hline $\begin{array}{l}\text { Temsirolimus mTORi } \\
\text { Vinorelbine }\end{array}$ & Unresectable or metastatic solid tumors & $\begin{array}{l}\text { Nonrandomized, } \\
\text { Open label, phase I }\end{array}$ & $\begin{array}{c}19 \\
\text { actual }\end{array}$ & DLTs, ORR & Completed & NCT01155258 \\
\hline $\begin{array}{l}\text { Ciclophosfamide } \\
\text { Sirolimus mTORi }\end{array}$ & $\begin{array}{l}\text { Metastatic, RAI-refractory, differentiated } \\
\text { thyroid cancer }\end{array}$ & $\begin{array}{l}\text { Nonrandomized, } \\
\text { Open label, phase II }\end{array}$ & $\begin{array}{c}19 \\
\text { estimated }\end{array}$ & ORR & Recruiting & NCT03099356 \\
\hline $\begin{array}{l}\text { Grapefruit juice } \\
\text { Sirolimus }{ }^{\text {mTORi }} \\
\end{array}$ & Advanced malignancies & $\begin{array}{l}\text { Nonrandomized, } \\
\text { Open label, phase Ib }\end{array}$ & $\begin{array}{c}41 \\
\text { actual }\end{array}$ & PK & Completed & NCT00375245 \\
\hline $\begin{array}{c}\text { Iodine I-131 } \\
\text { Selumetinib MEKi }\end{array}$ & Recurrent or metastatic thyroid cancer & $\begin{array}{c}\text { Randomized, } \\
\text { Double blind, phase II }\end{array}$ & $\begin{array}{c}60 \\
\text { estimated } \\
\end{array}$ & ORR & Recruiting & NCT02393690 \\
\hline $\begin{array}{l}\text { Olaparib PARPi } \\
\text { Selumetinib MEKi }\end{array}$ & $\begin{array}{c}\text { Endometrial, ovarian and other solid } \\
\text { tumors with RAS pathway alterations } \\
\text { and ovarian tumors with resistance to } \\
\text { PARPis }\end{array}$ & $\begin{array}{l}\text { Nonrandomized, } \\
\text { Open label, phase I }\end{array}$ & $\begin{array}{c}90 \\
\text { estimated }\end{array}$ & DLTs & Recruiting & NCT03162627 \\
\hline $\begin{array}{c}\text { Paclitaxel } \\
\text { Trametinib MEKi }\end{array}$ & Anaplastic thyroid cancer & $\begin{array}{l}\text { Nonrandomized, } \\
\text { Open label, early } \\
\text { phase I }\end{array}$ & $\begin{array}{c}12 \\
\text { estimated }\end{array}$ & PFS & Recruiting & NCT03085056 \\
\hline $\begin{array}{l}\text { Dabrafenib BRAFi } \\
\text { Trametinib MEKi }\end{array}$ & Recurrent thyroid cancer & $\begin{array}{c}\text { Randomized, } \\
\text { Open label, phase II }\end{array}$ & $\begin{array}{c}53 \\
\text { actual }\end{array}$ & ORR & Active, not Recruiting & NCT01723202 \\
\hline $\begin{array}{l}\text { Dabrafenib BRAFi } \\
\text { Trametinib MEKi }\end{array}$ & $\begin{array}{c}\text { Refractory metastatic differentiated } \\
\text { thyroid cancer with } R A S \text { or } B R A F^{V 600 \mathrm{E}} \\
\text { mutations }\end{array}$ & $\begin{array}{l}\text { Nonrandomized, } \\
\text { Open label, phase II }\end{array}$ & $\begin{array}{c}87 \\
\text { estimated }\end{array}$ & ORR & Recruiting & NCT03244956 \\
\hline $\begin{array}{l}\text { Pazopanib MKi } \\
\text { Trametinib MEKi }\end{array}$ & $\begin{array}{l}\text { Advanced solid tumors enriched for } \\
\text { patients with differentiated thyroid } \\
\text { cancer, soft tissue sarcoma, and } \\
\text { cholangiocarcinoma }\end{array}$ & $\begin{array}{l}\text { Nonrandomized, } \\
\text { Open label, phase I }\end{array}$ & $\begin{array}{c}89 \\
\text { actual }\end{array}$ & DLTs, SP & Completed & NCT01438554 \\
\hline $\begin{array}{c}\text { RAI } \\
\text { Trametinib }^{\text {MEKi }}\end{array}$ & $\begin{array}{l}\text { Mutant } R A S \text { or wild-type } R A S / R A F, \\
\text { RAI-refractory recurrent and/or } \\
\text { metastatic thyroid cancer }\end{array}$ & $\begin{array}{l}\text { Nonrandomized, } \\
\text { Open label, phase II }\end{array}$ & $\begin{array}{c}35 \\
\text { estimated }\end{array}$ & PFS, ORR & Recruiting & NCT02152995 \\
\hline Cobimetinib $^{\mathrm{MEKi}}$ & $\begin{array}{l}\text { Differentiated, poorly differentiated and } \\
\text { anaplastic thyroid carcinomas }\end{array}$ & $\begin{array}{l}\text { Nonrandomized, } \\
\text { Open label, phase II }\end{array}$ & $\begin{array}{c}50 \\
\text { estimated }\end{array}$ & OS & Recruiting & NCT03181100 \\
\hline
\end{tabular}

Acronyms: Complete remission rate (CRR); Dose-limiting toxicities (DLTs); Objective response rate (ORR); Overall survival (OS); Pharmacodynamic (PD); Pharmacokinetics (PK); Progression-free survival (PFS); Safety profile (SP). 


\subsection{IGF-IR Direct Inhibitors}

Agents exerting IGF-IR inhibition include monoclonal antibodies (mAbs) targeting IGF-IR (IGF-IR ${ }^{\mathrm{mAbs}}$ ) and tyrosine kinase inhibitors (TKIs) binding to the IGF-IR catalytic domain (IGF-IR ${ }^{\text {TKIs }}$ ) [6] . Disappointingly, clinical trials employing these agents showed modest reductions in tumor growth as multiple resistance mechanisms (an IGF2/IRA autocrine signaling loop or rising levels of circulating IGF-IR that sequesters IGF-IR inhibitors) quickly overcame their IGF-IR inhibition [54]. Thus, further preclinical and clinical studies have combined IGF-IR ${ }^{\mathrm{mAbs}}$ and IGF-IR ${ }^{\mathrm{TKI}}$ with different anticancer drugs.

A comprehensive description of their possible use in the preclinical or clinical settings both, in monotherapy or in combination with additional pharmacological compounds is included below.

\subsubsection{IGF-IR ${ }^{\mathrm{mAbs}}$}

IGF-IR ${ }^{\text {Abs }}$ block ligand-receptor interactions, causing receptor internalization and degradation and thereby quenching IGF-IR-mediated intracellular signaling. Several IGF-IR ${ }^{\mathrm{mAbs}}$ have been generated and tested in different tumor types [6] but only AVE1642, cixutumumab and ganitumab were employed for the treatment of thyroid carcinomas.

\section{AVE1642}

A phase I study evaluated the efficacy of the combination of AVE1642 with docetaxel in a cohort of patients affected by different tumor types including one patient with thyroid carcinoma. More than $50 \%$ of subjects enrolled in this group achieved stable disease [61].

\section{Cixutumumab (IMAC-A12)}

Preclinical studies evaluated the efficacy of cixitumumab both in vitro and in vivo using an orthotopic mouse model of ATC [82]. In this study, cixutumumab decreased IGF-IR phosphorylation in a dose dependent manner. However, this inhibition only translated in a weak reduction of cell proliferation. Interestingly, combining cixutumumab with irinotecan induced cell death in vitro and strongly reduced tumor volume in the mouse model, improving survival rates compared to irinotecan alone. Following these experimental findings, two clinical trials investigated the combination of cixutumumab and different anticancer drugs in patients with thyroid carcinoma. In a phase I trial (NCT01061749), the association of cixutumumab with the MEK1/2 inhibitor selumetinib, improved time to tumor progression [62], while a nonrandomized open label phase I trial (NCT01204476) tested the association of cixutumumab with the mTOR inhibitor everolimus and octreotide in several tumor types including medullary thyroid carcinoma. To date, no results have been posted on this study.

\section{Ganitumab (AMG-479)}

A phase $\mathrm{Ib}$ basket trial investigated dual treatment with ganitumab and sorafenib or panitumumab in two patients with thyroid carcinoma [63]. In this study, the association of ganitumab with sorafenib decreased tumor size, while the combination with panitumumab only reduced tumor growth. In both patients, the best clinical response detected was disease stability.

Despite the attractive role of IGF-IR ${ }^{\mathrm{mAbs}}$ as anticancer agents, an important implication concerning their adverse events profile (AEs) must be considered. These pitfalls were reported in different clinical studies and include severe AEs such as early fatal toxicities [83], hyper- or hypoglycemia, immune system impairment and cardiotoxicity [84]. Hence, when IGF-IR ${ }^{\mathrm{mAbs}}$ as used as anticancer agents, it is essential apply the correct combination with other anticancer drugs in order to reduce the AEs.

\subsubsection{IGF-IR ${ }^{\mathrm{TKI}}$}

IGF-IR ${ }^{\text {TKIs }}$ are small molecules that bind and functionally inhibit the IGF-IR catalytic domain. Currently, only results with linsitinib, NVP-ADW742, and NVP-AEW541 have been reported. 
Linsitinib

The biological cooperation between TSH and IGF-IR was investigated in primary human thyrocytes where linsitinib inhibited TSH-mediated NIS stimulation that requires ERK and/or AKT signaling. These data highlight the importance of the TSH/IGF-IR crosstalk in thyroid cancer [41].

\section{NVP-ADW742}

Constantine and colleagues evaluated the efficacy of NVP-ADW742 against multiple tumor cell types including thyroid carcinoma cell lines. They observed that NVP-ADW742 reduces IGF-IR phosphorylation after IGF-I stimulation and inhibits cell proliferation [85].

\section{NVP-AEW541}

WRO thyroid cancer cells genetically modified to express the IGF-IR were implanted in thyroid glands of athymic mice and exposed to NVP-AEW541 or irinotecan, used as a reference treatment. NVP-AEW541 inhibited tumor growth more potently than irinotecan. Furthermore, NVP-AEW541 also reduced tumor angiogenesis, suggesting that IGF-IR modulates thyroid tumor microenvironment [86].

\subsection{Inhibitors Targeting Downstream Signaling Mediators Shared by IGF-IR/RTKs (IGF-IR/RTKs Downstream Inhibitors)}

A further therapeutic strategy examined in thyroid carcinomas relies on agents that interfere with the complex downstream signaling generated by the crosstalk between IGF-IR and other RTKs $[16,45,51,87,88]$. Preclinical and/or clinical results demonstrate that PI3K, AKT, mTOR, MEK and FAK inhibitors (i), alone or in combination, display therapeutic potential against thyroid carcinoma cells.

\subsubsection{PI3Ki/AKTi/mTORi}

Aberrant activation of PI3K/AKT/mTOR signaling heavily contributes to thyroid tumorigenesis [89-91]. Hence, these IGF signaling mediators have been extensively investigated as possible therapeutic targets for thyroid cancer treatment [92,93]. A synopsis of the data available to date is summarized below.

Buparlisib (PI3Ki)

A phase I and a phase II clinical trial enrolling patients with refractory FTC and PDTC failed to detect reductions in tumor growth after buparlisib treatment $[64,65]$. These observations suggested that the triple combination of a PI3Ki, an AKTi and a MEKi might be more successful. Indeed, a trial with a PI3Ki (copanlisib, taselisib and GSK2636771) combined with an AKTi (capivasertib) and a MEKi (trametinib or binimetinib) is currently ongoing (NCT02465060).

Ipatasertib (AKTi)

A phase I study tested the drug's efficacy in different tumor types including one patient with thyroid carcinoma. No results have yet been reported [66].

Everolimus (mTORi)

This mTOR inhibitor generated contrasting results when employed on thyroid tumors as efficacy was mostly dependent on tumor type and stage. Indeed, while low response rates were reported in patients with locally advanced or metastatic thyroid cancer [77], everolimus displayed antitumor activity in patients with advanced FTC [80] or MTC [78] and induced disease stability in an ATC case series [75]. Finally, the combination of everolimus and cisplatin [76] or sorafenib [79] showed clinical efficacy both in DTCs and MTCs. 
Sirolimus (mTORi)

A retrospective study evaluated the efficacy of sirolimus and cyclophosphamide in patients with advanced differentiated thyroid carcinoma. The association was well tolerated, but no differences in progression-free survival were detected between patients in the experimental arm and those allocated to the control group (receiving standard of care for disease progression) [94].

Temsirolimus (mTORi)

The ability of temsirolimus to interfere with thyroid tumor growth was described in association with anti-angiogenic agent (trebaninib) or multikinase inhibitor (sorafenib). Specifically, a phase I trial enrolling patients with different tumor types including one with thyroid carcinoma found that the association of temsirolimus and trebaninib induced a partial response [81]. A more potent inhibition of thyroid cancer growth was achieved by combining temsirolimus and sorafenib. In detail, 36 patients affected by metastatic radioiodine-refractory thyroid cancer received the two drugs attaining stable disease in $58 \%$ of cases, a 1-year progression-free survival rate of $30.5 \%$ and an overall survival of 24.6 months [79]. Moreover, an open label phase I trial is ongoing to evaluate the efficacy of temsirolimus associated with bevacizumab or vinorelbine in patients with advanced thyroid cancer (NCT01552434 and NCT01155258).

\subsubsection{MEKi}

Aberrant activation of intracellular signaling involving the MEK pathway contributes to thyroid tumorigenesis since MEK inhibition favors differentiation of radioiodine-refractory DTCs by restoring NIS expression $[86,95,96]$. Hence, a number of specific MEKi have been evaluated in preclinical and clinical studies including several samples/patients diagnosed with thyroid cancer [97-99].

\section{Binimetinib and Pimasertib}

Two phase I studies investigated the efficacy of binimetinib and the association of pimasertib with temsirolimus in patients with advanced solid tumors including thyroid cancer. However, no data have yet been reported with the exception of a case report describing a patient receiving binimetinib that achieved a partial response (tumor shrinkage $>30 \%$ ) $[69,70]$.

\section{Selumetinib}

In a clinical trial (NCT009700359) enrolling 24 patients with thyroid cancer refractory to radioiodine, selumetinib generated clinically meaningful increases in iodine uptake [100]. This important observation, spurred an additional study that is evaluating Iodine- 131 combined with selumetinib (NTC02393690). In a phase I clinical trial, Infante and colleagues reported a series of patients with different tumor types (two thyroid carcinomas) exposed to the association of selumetinib and temsirolimus. The entire cohort displayed stable disease status [71]. Finally, a phase II study that accrued 39 patients with radioiodine-refractory PTCs demonstrated that selumetinib was ineffective in patients with the $B-R A F^{\mathrm{V} 600 \mathrm{E}}$ mutation [72].

\section{Trametinib}

This compound is an allosteric MEK inhibitor with documented anti-tumor activity against thyroid cancer. A phase I dose-escalating basket trial evaluated trametinib efficacy in five patients with thyroid carcinomas. All patients achieved stable disease or partial responses [73]. A phase IB trial assessed the combination of trametinib and everolimus in 67 patients with advanced solid tumors (one diagnosed with thyroid cancer), but the response achieved by this patient has not been reported [74]. Several additional clinical studies combining trametinib with other anticancer drugs in thyroid cancer are presently ongoing. 


\subsubsection{FAKi}

Although both in vitro and in vivo models have demonstrated an active role for FAK in thyroid tumorigenesis [16,101-104], no meaningful data have been reported in thyroid cancer patients. Two phase-I studies employing the FAK inhibitors VS-6063 and GSK2256098 in three patients with advanced thyroid cancer failed to describe any clinically significant results. This observation may be explained by the observation that blocking FAK prevents tumor invasion but likely doesn't influence tumor size $[67,68]$. To date, no clinical trials investigating FAK inhibitors in thyroid cancer are available.

\section{Conclusions}

In the last few years, the incidence of thyroid carcinoma is increasing across multiple countries [31]. Although most thyroid tumors are DTCs with good prognosis, PDTCs and ATCs display unfavorable outcomes requiring new therapeutic options [51].

Increased understanding of cancer biology has led to the development of anticancer drugs targeting specific oncogenic substrates such as AKT, BCR-ABL1, EGFR, MET, and the IGF-IR. Since the IGF system is often deregulated in thyroid cancer, it has been considered an attractive pharmacological target for this disease [10]. However, compounds that directly interfere with IGF-IR activity failed to demonstrate meaningful clinical activity [6]. Different hypotheses have been developed to explain their weak efficacy in thyroid carcinomas including: (i) the persistent activation of an IGF-2-IR-A autocrine loop favoring cancer progression [6,105], (ii) IGF-IR crosstalk with other RTKs [51], compensatory intracellular signaling causing loss of therapeutic efficacy [106] and (iii) molecular alterations in RTK downstream targets (e.g., RAS or B-RAF) driving cell growth regardless of IGF inhibition [33].

In this complex scenario, combined targeted regimens may overcome these resistance phenomena and improve patient response rates [21,107-110]. Thus, dual inhibition approaches using both IGF-IR and RTKs antagonists have been investigated, but these combinations have resulted in disease stability without relevant tumor shrinkage.

Among the most promising pharmacological agents targeting downstream signaling mediators shared by both IGF-IR and RTKs, the combination of anti-mTOR compounds with different kinase inhibitors has generated encouraging reductions in tumor growth [48]. MEK inhibitors could also represent a possible therapeutic approach as these drugs may restore NIS expression in patients with radioiodine-refractory thyroid carcinoma.

In summary, while multiple pharmacological approaches aimed against the IGF axis have been actively investigated for the treatment of PDTCs and ATCs, further biological studies and additional compounds and/or pharmacological strategies will be required to significantly improve the outcome of these aggressive forms of thyroid cancer.

Author Contributions: Conceptualization, L.M. and P.V.; formal analysis, M.S.P.; data curation, L.M., M.M., S.S., F.M., and G.M.; writing-original draft preparation, L.M., M.M., and S.S.; writing—review and editing, L.M., M.M., S.S., E.T., M.S.P, F.M., G.M., S.R.V., A.P., C.R., S.D.G., M.R., P.M., and P.V.; supervision, P.V.

Funding: This research received no external funding.

Conflicts of Interest: The authors declare no conflict of interest.

\section{Abbreviations}

ATC Anaplastic Thyroid Cancer

AKT V-Akt Murine Thymoma Viral Oncogene Homolog

AKTi V-Akt Murine Thymoma Viral Oncogene Homolog inihibitors

ALK Anaplastic Lymphoma Kinase

DDR1 Discoidin Domain Receptor Tyrosine Kinase 1

DTC Differentiated Thyroid Cancer 


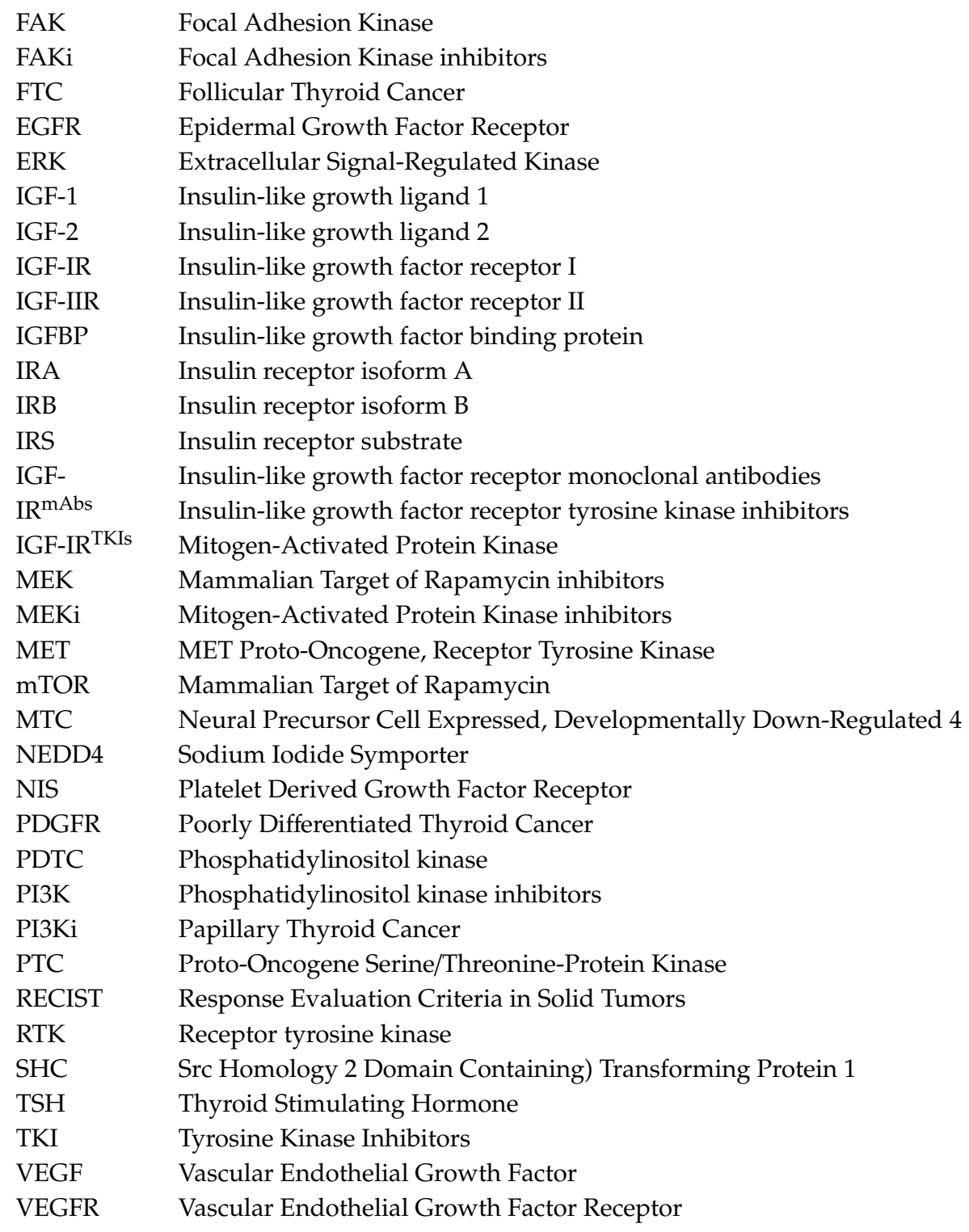

\section{References}

1. Bowers, L.W.; Rossi, E.L.; O'Flanagan, C.H.; deGraffenried, L.A.; Hursting, S.D. The role of the insulin/igf system in cancer: Lessons learned from clinical trials and the energy balance-cancer link. Front. Endocrinol (Lausanne) 2015, 6, 77. [CrossRef]

2. Delafontaine, P.; Song, Y.H.; Li, Y. Expression, regulation, and function of igf-1, igf-1r, and igf-1 binding proteins in blood vessels. Arterioscl. Throm. Vas. 2004, 24, 435-444. [CrossRef] [PubMed]

3. Allard, J.B.; Duan, C. Igf-binding proteins: Why do they exist and why are there so many? Front. Endocrinol. (Lausanne) 2018, 9, 117. [CrossRef] [PubMed]

4. Brahmkhatri, V.P.; Prasanna, C.; Atreya, H.S. Insulin-like growth factor system in cancer: Novel targeted therapies. Biomed. Res. Int. 2015, 2015, 538019. [CrossRef] [PubMed]

5. Pollak, M. The insulin and insulin-like growth factor receptor family in neoplasia: An update. Nat. Rev. Cancer 2012, 12, 159-169. [CrossRef] [PubMed]

6. Simpson, A.; Petnga, W.; Macaulay, V.M.; Weyer-Czernilofsky, U.; Bogenrieder, T. Insulin-like growth factor (igf) pathway targeting in cancer: Role of the igf axis and opportunities for future combination studies. Target. Oncol. 2017, 12, 571-597. [CrossRef]

7. Baxter, R.C. Igf binding proteins in cancer: Mechanistic and clinical insights. Nat. Rev. Cancer 2014, 14, 329-341. [CrossRef] 
8. Li, R.; Pourpak, A.; Morris, S.W. Inhibition of the insulin-like growth factor-1 receptor (igf1r) tyrosine kinase as a novel cancer therapy approach. J. Med. Chem. 2009, 52, 4981-5004. [CrossRef]

9. Malaguarnera, R.; Belfiore, A. The insulin receptor: A new target for cancer therapy. Front. Endocrinol. (Lausanne) 2011, 2, 93. [CrossRef]

10. Vella, V.; Malaguarnera, R. The emerging role of insulin receptor isoforms in thyroid cancer: Clinical implications and new perspectives. Int. J. Mol. Sci. 2018, 19, 3814. [CrossRef]

11. Crudden, C.; Girnita, A.; Girnita, L. Targeting the igf-1r: The tale of the tortoise and the hare. Front. Endocrinol. (Lausanne) 2015, 6, 64. [CrossRef] [PubMed]

12. Ochnik, A.M.; Baxter, R.C. Combination therapy approaches to target insulin-like growth factor receptor signaling in breast cancer. Endocr. Relat. Cancer 2016, 23, R513-R536. [CrossRef] [PubMed]

13. Sciacca, L.; Vella, V.; Frittitta, L.; Tumminia, A.; Manzella, L.; Squatrito, S.; Belfiore, A.; Vigneri, R. Long-acting insulin analogs and cancer. Nutr. Metab. Cardiovasc. Dis. 2018, 28, 436-443. [CrossRef] [PubMed]

14. Ciampolillo, A.; De Tullio, C.; Giorgino, F. The igf-i/igf-i receptor pathway: Implications in the pathophysiology of thyroid cancer. Curr. Med. Chem. 2005, 12, 2881-2891. [CrossRef]

15. Vigneri, P.G.; Tirro, E.; Pennisi, M.S.; Massimino, M.; Stella, S.; Romano, C.; Manzella, L. The insulin/igf system in colorectal cancer development and resistance to therapy. Front. Oncol. 2015, 5, 230. [CrossRef] [PubMed]

16. Jin, S.; Borkhuu, O.; Bao, W.; Yang, Y.T. Signaling pathways in thyroid cancer and their therapeutic implications. J. Clin. Med. Res. 2016, 8, 284-296. [CrossRef] [PubMed]

17. Manzella, L.; Stella, S.; Pennisi, M.S.; Tirro, E.; Massimino, M.; Romano, C.; Puma, A.; Tavarelli, M.; Vigneri, P. New insights in thyroid cancer and p53 family proteins. Int. J. Mol. Sci. 2017, 18, 1325. [CrossRef]

18. Massimino, M.; Vigneri, P.; Fallica, M.; Fidilio, A.; Aloisi, A.; Frasca, F.; Manzella, L. Irf5 promotes the proliferation of human thyroid cancer cells. Mol. Cancer 2012, 11, 21. [CrossRef]

19. Vella, V.; Puppin, C.; Damante, G.; Vigneri, R.; Sanfilippo, M.; Vigneri, P.; Tell, G.; Frasca, F. Deltanp73alpha inhibits pten expression in thyroid cancer cells. Int. J. Cancer 2009, 124, 2539-2548. [CrossRef]

20. Vigneri, R.; Malandrino, P.; Giani, F.; Russo, M.; Vigneri, P. Heavy metals in the volcanic environment and thyroid cancer. Mol. Cell. Endocrinol. 2017, 457, 73-80. [CrossRef]

21. Massimino, M.; Tirro, E.; Stella, S.; Frasca, F.; Vella, V.; Sciacca, L.; Pennisi, M.S.; Vitale, S.R.; Puma, A.; Romano, C.; et al. Effect of combined epigenetic treatments and ectopic nis expression on undifferentiated thyroid cancer cells. Anticancer Res. 2018, 38, 6653-6662. [CrossRef] [PubMed]

22. Grimm, D. Current knowledge in thyroid cancer-from bench to bedside. Int. J. Mol. Sci. 2017, $18,1529$. [CrossRef] [PubMed]

23. Vella, V.; Sciacca, L.; Pandini, G.; Mineo, R.; Squatrito, S.; Vigneri, R.; Belfiore, A. The igf system in thyroid cancer: New concepts. Mol. Pathol. 2001, 54, 121-124. [CrossRef] [PubMed]

24. Kimura, T.; Van Keymeulen, A.; Golstein, J.; Fusco, A.; Dumont, J.E.; Roger, P.P. Regulation of thyroid cell proliferation by tsh and other factors: A critical evaluation of in vitro models. Endocr. Rev. 2001, 22, 631-656. [CrossRef] [PubMed]

25. Malaguarnera, R.; Morcavallo, A.; Belfiore, A. The insulin and igf-i pathway in endocrine glands carcinogenesis. J. Oncol. 2012, 2012, 635614. [CrossRef] [PubMed]

26. Liu, Y.J.; Qiang, W.; Shi, J.; Lv, S.Q.; Ji, M.J.; Shi, B.Y. Expression and significance of igf-1 and igf-1r in thyroid nodules. Endocrine 2013, 44, 158-164. [CrossRef]

27. Belfiore, A.; Pandini, G.; Vella, V.; Squatrito, S.; Vigneri, R. Insulin/igf-i hybrid receptors play a major role in igf-i signaling in thyroid cancer. Biochimie 1999, 81, 403-407. [CrossRef]

28. Schmidt, J.A.; Allen, N.E.; Almquist, M.; Franceschi, S.; Rinaldi, S.; Tipper, S.J.; Tsilidis, K.K.; Weiderpass, E.; Overvad, K.; Tjonneland, A.; et al. Insulin-like growth factor-i and risk of differentiated thyroid carcinoma in the european prospective investigation into cancer and nutrition. Cancer Epidemiol. Biomarkers Prev. 2014, 23, 976-985. [CrossRef]

29. Firth, S.M.; Baxter, R.C. Cellular actions of the insulin-like growth factor binding proteins. Endocr. Rev. 2002, 23, 824-854. [CrossRef]

30. LeRoith, D.; Roberts, C.T., Jr. The insulin-like growth factor system and cancer. Cancer Lett. 2003, 195, 127-137. [CrossRef]

31. Vigneri, R.; Malandrino, P.; Vigneri, P. The changing epidemiology of thyroid cancer: Why is incidence increasing? Curr. Opin. Oncol. 2015, 27, 1-7. [CrossRef] [PubMed] 
32. Modric, T.; Rajkumar, K.; Murphy, L.J. Thyroid gland function and growth in igf binding protein-1 transgenic mice. Eur. J. Endocrinol. 1999, 141, 149-159. [CrossRef] [PubMed]

33. Fakhruddin, N.; Jabbour, M.; Novy, M.; Tamim, H.; Bahmad, H.; Farhat, F.; Zaatari, G.; Aridi, T.; Kriegshauser, G.; Oberkanins, C.; et al. Braf and nras mutations in papillary thyroid carcinoma and concordance in braf mutations between primary and corresponding lymph node metastases. Sci. Rep. 2017, 7, 4666. [CrossRef] [PubMed]

34. Cohen, P. The twentieth century struggle to decipher insulin signalling. Nat. Rev. Mol. Cell. Biol. 2006, 7, 867-873. [CrossRef] [PubMed]

35. Taniguchi, C.M.; Emanuelli, B.; Kahn, C.R. Critical nodes in signalling pathways: Insights into insulin action. Nat. Rev. Mol. Cell. Biol. 2006, 7, 85-96. [CrossRef] [PubMed]

36. Averous, J.; Fonseca, B.D.; Proud, C.G. Regulation of cyclin d1 expression by mtorc1 signaling requires eukaryotic initiation factor 4e-binding protein 1. Oncogene 2008, 27, 1106-1113. [CrossRef] [PubMed]

37. Bhaskar, P.T.; Hay, N. The two torcs and akt. Dev. Cell. 2007, 12, 487-502. [CrossRef]

38. Chitnis, M.M.; Yuen, J.S.; Protheroe, A.S.; Pollak, M.; Macaulay, V.M. The type 1 insulin-like growth factor receptor pathway. Clin. Cancer Res. 2008, 14, 6364-6370. [CrossRef]

39. Brewer, C.; Yeager, N.; Di Cristofano, A. Thyroid-stimulating hormone initiated proliferative signals converge in vivo on the mtor kinase without activating akt. Cancer Res. 2007, 67, 8002-8006. [CrossRef]

40. Fiore, E.; Rago, T.; Provenzale, M.A.; Scutari, M.; Ugolini, C.; Basolo, F.; Di Coscio, G.; Berti, P.; Grasso, L.; Elisei, R.; et al. Lower levels of tsh are associated with a lower risk of papillary thyroid cancer in patients with thyroid nodular disease: Thyroid autonomy may play a protective role. Endocr. Relat. Cancer 2009, 16, 1251-1260. [CrossRef]

41. Morgan, S.J.; Neumann, S.; Marcus-Samuels, B.; Gershengorn, M.C. Thyrotropin and insulin-like growth factor 1 receptor crosstalk upregulates sodium-iodide symporter expression in primary cultures of human thyrocytes. Thyroid 2016, 26, 1794-1803. [CrossRef] [PubMed]

42. Fukushima, T.; Yoshihara, H.; Furuta, H.; Kamei, H.; Hakuno, F.; Luan, J.; Duan, C.; Saeki, Y.; Tanaka, K.; Iemura, S.; et al. Nedd4-induced monoubiquitination of irs-2 enhances igf signalling and mitogenic activity. Nat. Commun. 2015, 6, 6780. [CrossRef] [PubMed]

43. Herkert, B.; Kauffmann, A.; Molle, S.; Schnell, C.; Ferrat, T.; Voshol, H.; Juengert, J.; Erasimus, H.; Marszalek, G.; Kazic-Legueux, M.; et al. Maximizing the efficacy of mapk-targeted treatment in ptenlof/brafmut melanoma through pi3k and igf1r inhibition. Cancer Res. 2016, 76, 390-402. [CrossRef] [PubMed]

44. Chakravarti, A.; Loeffler, J.S.; Dyson, N.J. Insulin-like growth factor receptor i mediates resistance to anti-epidermal growth factor receptor therapy in primary human glioblastoma cells through continued activation of phosphoinositide 3-kinase signaling. Cancer Res. 2002, 62, 200-207. [PubMed]

45. Liu, C.; Zhang, Z.; Tang, H.; Jiang, Z.; You, L.; Liao, Y. Crosstalk between igf-1r and other tumor promoting pathways. Curr. Pharm. Des. 2014, 20, 2912-2921. [CrossRef] [PubMed]

46. Vella, V.; Malaguarnera, R.; Nicolosi, M.L.; Palladino, C.; Spoleti, C.; Massimino, M.; Vigneri, P.; Purrello, M.; Ragusa, M.; Morrione, A.; et al. Discoidin domain receptor 1 modulates insulin receptor signaling and biological responses in breast cancer cells. Oncotarget 2017, 8, 43248-43270. [CrossRef] [PubMed]

47. Vella, V.; Nicolosi, M.L.; Cantafio, P.; Massimino, M.; Lappano, R.; Vigneri, P.; Ciuni, R.; Gangemi, P.; Morrione, A.; Malaguarnera, R.; et al. Ddr1 regulates thyroid cancer cell differentiation via igf-2/ir-a autocrine signaling loop. Endocr. Relat. Cancer 2019, 26, 197-214. [CrossRef]

48. Guigon, C.J.; Fozzatti, L.; Lu, C.; Willingham, M.C.; Cheng, S.Y. Inhibition of mtorc1 signaling reduces tumor growth but does not prevent cancer progression in a mouse model of thyroid cancer. Carcinogenesis 2010, 31, 1284-1291. [CrossRef]

49. Laursen, R.; Wehland, M.; Kopp, S.; Pietsch, J.; Infanger, M.; Grosse, J.; Grimm, D. Effects and role of multikinase inhibitors in thyroid cancer. Curr. Pharm. Des. 2016, 22, 5915-5926. [CrossRef]

50. Montero-Conde, C.; Ruiz-Llorente, S.; Dominguez, J.M.; Knauf, J.A.; Viale, A.; Sherman, E.J.; Ryder, M.; Ghossein, R.A.; Rosen, N.; Fagin, J.A. Relief of feedback inhibition of her3 transcription by raf and mek inhibitors attenuates their antitumor effects in braf-mutant thyroid carcinomas. Cancer Dis. 2013, 3, 520-533. [CrossRef]

51. Naoum, G.E.; Morkos, M.; Kim, B.; Arafat, W. Novel targeted therapies and immunotherapy for advanced thyroid cancers. Mol. Cancer 2018, 17, 51. [CrossRef] [PubMed] 
52. Arcaro, A. Targeting the insulin-like growth factor-1 receptor in human cancer. Front. Pharm. 2013, 4, 30. [CrossRef] [PubMed]

53. Denduluri, S.K.; Idowu, O.; Wang, Z.; Liao, Z.; Yan, Z.; Mohammed, M.K.; Ye, J.; Wei, Q.; Wang, J.; Zhao, L.; et al. Insulin-like growth factor (igf) signaling in tumorigenesis and the development of cancer drug resistance. Genes Dis. 2015, 2, 13-25. [CrossRef] [PubMed]

54. Janssen, J.A.; Varewijck, A.J. Igf-ir targeted therapy: Past, present and future. Front. Endocrinol. (Lausanne) 2014, 5, 224. [CrossRef] [PubMed]

55. Wilson, T.R.; Fridlyand, J.; Yan, Y.; Penuel, E.; Burton, L.; Chan, E.; Peng, J.; Lin, E.; Wang, Y.; Sosman, J.; et al. Widespread potential for growth-factor-driven resistance to anticancer kinase inhibitors. Nature 2012, 487, 505-509. [CrossRef] [PubMed]

56. Awasthi, N.; Zhang, C.; Ruan, W.; Schwarz, M.A.; Schwarz, R.E. Bms-754807, a small-molecule inhibitor of insulin-like growth factor-1 receptor/insulin receptor, enhances gemcitabine response in pancreatic cancer. Mol. Cancer. Ther. 2012, 11, 2644-2653. [CrossRef] [PubMed]

57. Chitnis, M.M.; Lodhia, K.A.; Aleksic, T.; Gao, S.; Protheroe, A.S.; Macaulay, V.M. Igf-1r inhibition enhances radiosensitivity and delays double-strand break repair by both non-homologous end-joining and homologous recombination. Oncogene 2014, 33, 5262-5273. [CrossRef]

58. Ferte, C.; Loriot, Y.; Clemenson, C.; Commo, F.; Gombos, A.; Bibault, J.E.; Fumagalli, I.; Hamama, S.; Auger, N.; Lahon, B.; et al. Igf-1r targeting increases the antitumor effects of DNA-damaging agents in sclc model: An opportunity to increase the efficacy of standard therapy. Mol. Cancer Ther. 2013, 12, 1213-1222. [CrossRef]

59. Ireland, L.; Santos, A.; Ahmed, M.S.; Rainer, C.; Nielsen, S.R.; Quaranta, V.; Weyer-Czernilofsky, U.; Engle, D.D.; Perez-Mancera, P.A.; Coupland, S.E.; et al. Chemoresistance in pancreatic cancer is driven by stroma-derived insulin-like growth factors. Cancer Res. 2016, 76, 6851-6863. [CrossRef]

60. Davis, S.L.; Eckhardt, S.G.; Diamond, J.R.; Messersmith, W.A.; Dasari, A.; Weekes, C.D.; Lieu, C.H.; Kane, M.; Choon Tan, A.; Pitts, T.M.; et al. A phase i dose-escalation study of linsitinib (osi-906), a small-molecule dual insulin-like growth factor-1 receptor/insulin receptor kinase inhibitor, in combination with irinotecan in patients with advanced cancer. Oncologist 2018, 23, 1409-e1140. [CrossRef]

61. Macaulay, V.M.; Middleton, M.R.; Protheroe, A.S.; Tolcher, A.; Dieras, V.; Sessa, C.; Bahleda, R.; Blay, J.Y.; LoRusso, P.; Mery-Mignard, D.; et al. Phase i study of humanized monoclonal antibody ave1642 directed against the type 1 insulin-like growth factor receptor (igf-1r), administered in combination with anticancer therapies to patients with advanced solid tumors. Ann. Oncol. 2013, 24, 784-791. [CrossRef]

62. Wilky, B.A.; Rudek, M.A.; Ahmed, S.; Laheru, D.A.; Cosgrove, D.; Donehower, R.C.; Nelkin, B.; Ball, D.; Doyle, L.A.; Chen, H.; et al. A phase i trial of vertical inhibition of igf signalling using cixutumumab, an anti-igf-1r antibody, and selumetinib, an mek $1 / 2$ inhibitor, in advanced solid tumours. Br. J. Cancer 2015, 112, 24-31. [CrossRef] [PubMed]

63. Rosen, L.S.; Puzanov, I.; Friberg, G.; Chan, E.; Hwang, Y.C.; Deng, H.; Gilbert, J.; Mahalingam, D.; McCaffery, I.; Michael, S.A.; et al. Safety and pharmacokinetics of ganitumab (amg 479) combined with sorafenib, panitumumab, erlotinib, or gemcitabine in patients with advanced solid tumors. Clin. Cancer Res. 2012, 18, 3414-3427. [CrossRef] [PubMed]

64. Rodon, J.; Brana, I.; Siu, L.L.; De Jonge, M.J.; Homji, N.; Mills, D.; Di Tomaso, E.; Sarr, C.; Trandafir, L.; Massacesi, C.; et al. Phase I dose-escalation and -expansion study of buparlisib (BKM120), an oral pan-Class I PI3K inhibitor, in patients with advanced solid tumors. Invest. New Drugs. 2014, 32, 670-681. [CrossRef] [PubMed]

65. Borson-Chazot, F.; Dantony, E.; Illouz, F.; Lopez, J.; Niccoli, P.; Wasserman, J.; Do Cao, C.; Leboulleux, S.; Klein, M.; Tabarin, A.; et al. The TUTHYREF Network. Thyroic Cancer Nodules 2018, 28, 1174-1179.

66. Saura, C.; Roda, D.; Rosello, S.; Oliveira, M.; Macarulla, T.; Perez-Fidalgo, J.A.; Morales-Barrera, R.; Sanchis-Garcia, J.M.; Musib, L.; Budha, N.; et al. A first-in-human phase i study of the atp-competitive akt inhibitor ipatasertib demonstrates robust and safe targeting of akt in patients with solid tumors. Cancer Discov. 2017, 7, 102-113. [CrossRef]

67. Jones, S.F.; Siu, L.L.; Bendell, J.C.; Cleary, J.M.; Razak, A.R.; Infante, J.R.; Pandya, S.S.; Bedard, P.L.; Pierce, K.J.; Houk, B.; et al. A phase i study of vs-6063, a second-generation focal adhesion kinase inhibitor, in patients with advanced solid tumors. Invest. New Drugs 2015, 33, 1100-1107. [CrossRef] 
68. Soria, J.C.; Gan, H.K.; Blagden, S.P.; Plummer, R.; Arkenau, H.T.; Ranson, M.; Evans, T.R.; Zalcman, G.; Bahleda, R.; Hollebecque, A.; et al. A phase i, pharmacokinetic and pharmacodynamic study of gsk2256098, a focal adhesion kinase inhibitor, in patients with advanced solid tumors. Ann. Oncol. 2016, 27, 2268-2274. [CrossRef]

69. Watanabe, K.; Otsu, S.; Hirashima, Y.; Morinaga, R.; Nishikawa, K.; Hisamatsu, Y.; Shimokata, T.; Inada-Inoue, M.; Shibata, T.; Takeuchi, H.; et al. A phase i study of binimetinib (mek162) in japanese patients with advanced solid tumors. Cancer Chemother. Pharmacol. 2016, 77, 1157-1164. [CrossRef]

70. Mita, M.; Fu, S.; Piha-Paul, S.A.; Janku, F.; Mita, A.; Natale, R.; Guo, W.; Zhao, C.; Kurzrock, R.; Naing, A. Phase i trial of mek 1/2 inhibitor pimasertib combined with mtor inhibitor temsirolimus in patients with advanced solid tumors. Invest. New Drugs 2017, 35, 616-626. [CrossRef]

71. Infante, J.R.; Cohen, R.B.; Kim, K.B.; Burris, H.A., 3rd; Curt, G.; Emeribe, U.; Clemett, D.; Tomkinson, H.K.; LoRusso, P.M. A phase i dose-escalation study of selumetinib in combination with erlotinib or temsirolimus in patients with advanced solid tumors. Invest. New Drugs 2017, 35, 576-588. [CrossRef]

72. Hayes, D.N.; Lucas, A.S.; Tanvetyanon, T.; Krzyzanowska, M.K.; Chung, C.H.; Murphy, B.A.; Gilbert, J.; Mehra, R.; Moore, D.T.; Sheikh, A.; et al. Phase ii efficacy and pharmacogenomic study of selumetinib (azd6244; arry-142886) in iodine-131 refractory papillary thyroid carcinoma with or without follicular elements. Clin. Cancer Res. 2012, 18, 2056-2065. [CrossRef]

73. Infante, J.R.; Fecher, L.A.; Falchook, G.S.; Nallapareddy, S.; Gordon, M.S.; Becerra, C.; DeMarini, D.J.; Cox, D.S.; Xu, Y.; Morris, S.R.; et al. Safety, pharmacokinetic, pharmacodynamic, and efficacy data for the oral mek inhibitor trametinib: A phase 1 dose-escalation trial. Lancet Oncol. 2012, 13, 773-781. [CrossRef]

74. Tolcher, A.W.; Bendell, J.C.; Papadopoulos, K.P.; Burris, H.A., 3rd; Patnaik, A.; Jones, S.F.; Rasco, D.; Cox, D.S.; Durante, M.; Bellew, K.M.; et al. A phase ib trial of the oral mek inhibitor trametinib (gsk1120212) in combination with everolimus in patients with advanced solid tumors. Ann. Oncol. 2015, 26, 58-64. [CrossRef]

75. Harris, E.J.; Hanna, G.J.; Chau, N.; Rabinowits, G.; Haddad, R.; Margalit, D.N.; Schoenfeld, J.; Tishler, R.B.; Barletta, J.A.; Nehs, M.; et al. Everolimus in anaplastic thyroid cancer: A case series. Front. Oncol 2019, 9, 106. [CrossRef] [PubMed]

76. Fury, M.G.; Sherman, E.; Haque, S.; Korte, S.; Lisa, D.; Shen, R.; Wu, N.; Pfister, D. A phase i study of daily everolimus plus low-dose weekly cisplatin for patients with advanced solid tumors. Cancer Chemother. Pharmacol. 2012, 69, 591-598. [CrossRef] [PubMed]

77. Lim, S.M.; Chang, H.; Yoon, M.J.; Hong, Y.K.; Kim, H.; Chung, W.Y.; Park, C.S.; Nam, K.H.; Kang, S.W.; Kim, M.K.; et al. A multicenter, phase ii trial of everolimus in locally advanced or metastatic thyroid cancer of all histologic subtypes. Ann. Oncol. 2013, 24, 3089-3094. [CrossRef] [PubMed]

78. Schneider, T.C.; de Wit, D.; Links, T.P.; van Erp, N.P.; van der Hoeven, J.J.; Gelderblom, H.; van Wezel, T.; van Eijk, R.; Morreau, H.; Guchelaar, H.J.; et al. Beneficial effects of the mtor inhibitor everolimus in patients with advanced medullary thyroid carcinoma: Subgroup results of a phase ii trial. Int. J. Endocrinol. 2015, 2015, 348124. [CrossRef] [PubMed]

79. Sherman, E.J.; Dunn, L.A.; Ho, A.L.; Baxi, S.S.; Ghossein, R.A.; Fury, M.G.; Haque, S.; Sima, C.S.; Cullen, G.; Fagin, J.A.; et al. Phase 2 study evaluating the combination of sorafenib and temsirolimus in the treatment of radioactive iodine-refractory thyroid cancer. Cancer 2017, 123, 4114-4121. [CrossRef]

80. Schneider, T.C.; de Wit, D.; Links, T.P.; van Erp, N.P.; van der Hoeven, J.J.; Gelderblom, H.; Roozen, I.C.; Bos, M.; Corver, W.E.; van Wezel, T.; et al. Everolimus in patients with advanced follicular-derived thyroid cancer: Results of a phase ii clinical trial. J. Clin. Endocrinol. Metab. 2017, 102, 698-707. [CrossRef] [PubMed]

81. Chiu, J.W.; Hotte, S.J.; Kollmannsberger, C.K.; Renouf, D.J.; Cescon, D.W.; Hedley, D.; Chow, S.; Moscow, J.; Chen, Z.; Perry, M.; et al. A phase i trial of ang1/2-tie2 inhibitor trebaninib (amg386) and temsirolimus in advanced solid tumors (pjc008/ncimusical sharp9041). Invest. New Drugs 2016, 34, 104-111. [CrossRef]

82. Wang, Z.; Chakravarty, G.; Kim, S.; Yazici, Y.D.; Younes, M.N.; Jasser, S.A.; Santillan, A.A.; Bucana, C.D.; El-Naggar, A.K.; Myers, J.N. Growth-inhibitory effects of human anti-insulin-like growth factor-i receptor antibody (a12) in an orthotopic nude mouse model of anaplastic thyroid carcinoma. Clin. Cancer Res. 2006, 12, 4755-4765. [CrossRef] 
83. Langer, C.J.; Novello, S.; Park, K.; Krzakowski, M.; Karp, D.D.; Mok, T.; Benner, R.J.; Scranton, J.R.; Olszanski, A.J.; Jassem, J. Randomized, phase iii trial of first-line figitumumab in combination with paclitaxel and carboplatin versus paclitaxel and carboplatin alone in patients with advanced non-small-cell lung cancer. J. Clin. Oncol. 2014, 32, 2059-2066. [CrossRef]

84. Ma, H.; Zhang, T.; Shen, H.; Cao, H.; Du, J. The adverse events profile of anti-igf-1r monoclonal antibodies in cancer therapy. Br. J. Clin. Pharmacol. 2014, 77, 917-928. [CrossRef] [PubMed]

85. Mitsiades, C.S.; Mitsiades, N.S.; McMullan, C.J.; Poulaki, V.; Shringarpure, R.; Akiyama, M.; Hideshima, T.; Chauhan, D.; Joseph, M.; Libermann, T.A.; et al. Inhibition of the insulin-like growth factor receptor-1 tyrosine kinase activity as a therapeutic strategy for multiple myeloma, other hematologic malignancies, and solid tumors. Cancer Cell 2004, 5, 221-230. [CrossRef]

86. Chakravarty, G.; Mondal, D. Insulin-Like Growth Factor Receptor Signaling in Thyroid Cancers: Clinical Implications and Therapeutic Potential; IntechOpen: London, UK, 2012.

87. Licitra, L.; Locati, L.D.; Greco, A.; Granata, R.; Bossi, P. Multikinase inhibitors in thyroid cancer. Eur. J. Cancer 2010, 46, 1012-1018. [CrossRef]

88. Liu,Z.; Hou, P.; Ji, M.; Guan, H.; Studeman, K.; Jensen, K.; Vasko, V.; El-Naggar, A.K.; Xing, M. Highly prevalent genetic alterations in receptor tyrosine kinases and phosphatidylinositol 3-kinase/akt and mitogen-activated protein kinase pathways in anaplastic and follicular thyroid cancers. J. Clin. Endocrinol. Metab. 2008, 93, 3106-3116. [CrossRef] [PubMed]

89. Bozorg-Ghalati, F.; Hedayati, M.; Dianatpour, M.; Azizi, F.; Mosaffa, N.; Mehrabani, D. Effects of a phosphoinositide-3-kinase inhibitor on anaplastic thyroid cancer stem cells. Asian. Pac. J. Cancer Prev. 2017, 18, 2287-2291. [PubMed]

90. Nozhat, Z.; Hedayati, M. Pi3k/akt pathway and its mediators in thyroid carcinomas. Mol. Diagn. Ther. 2016, 20, 13-26. [CrossRef] [PubMed]

91. Shinohara, M.; Chung, Y.J.; Saji, M.; Ringel, M.D. Akt in thyroid tumorigenesis and progression. Endocrinology 2007, 148, 942-947. [CrossRef] [PubMed]

92. Petrulea, M.S.; Plantinga, T.S.; Smit, J.W.; Georgescu, C.E.; Netea-Maier, R.T. Pi3k/akt/mtor: A promising therapeutic target for non-medullary thyroid carcinoma. Cancer Treat. Rev. 2015, 41, 707-713. [CrossRef] [PubMed]

93. Manfredi, G.I.; Dicitore, A.; Gaudenzi, G.; Caraglia, M.; Persani, L.; Vitale, G. Pi3k/akt/mtor signaling in medullary thyroid cancer: A promising molecular target for cancer therapy. Endocrine 2015, 48, 363-370. [CrossRef] [PubMed]

94. Manohar, P.M.; Beesley, L.J.; Taylor, J.M.; Hesseltine, E.; Haymart, M.R.; Esfandiari, N.H.; Hanauer, D.A.; Worden, F.P. Retrospective study of sirolimus and cyclophosphamide in patients with advanced differentiated thyroid cancers. J. Thyroid. Disord. Ther. 2015, 4. [CrossRef] [PubMed]

95. Hong, C.M.; Ahn, B.C. Redifferentiation of radioiodine refractory differentiated thyroid cancer for reapplication of i-131 therapy. Front. Endocrinol. (Lausanne) 2017, 8, 260. [CrossRef] [PubMed]

96. Wachter, S.; Wunderlich, A.; Greene, B.H.; Roth, S.; Elxnat, M.; Fellinger, S.A.; Verburg, F.A.; Luster, M.; Bartsch, D.K.; Di Fazio, P. Selumetinib activity in thyroid cancer cells: Modulation of sodium iodide symporter and associated mirnas. Int. J. Mol. Sci. 2018, 19, 2077. [CrossRef] [PubMed]

97. Ball, D.W.; Jin, N.; Xue, P.; Bhan, S.; Ahmed, S.R.; Rosen, D.M.; Schayowitz, A.; Clark, D.P.; Nelkin, B.D. Trametinib with and without pazopanib has potent preclinical activity in thyroid cancer. Oncol. Rep. 2015, 34, 2319-2324. [CrossRef] [PubMed]

98. Liu, D.; Xing, M. Potent inhibition of thyroid cancer cells by the mek inhibitor pd0325901 and its potentiation by suppression of the pi3k and nf-kappab pathways. Thyroid 2008, 18, 853-864. [CrossRef]

99. Zhao, Y.; Adjei, A.A. The clinical development of mek inhibitors. Nat. Rev. Clin. Oncol. 2014, 11, 385-400. [CrossRef]

100. Ho, A.L.; Grewal, R.K.; Leboeuf, R.; Sherman, E.J.; Pfister, D.G.; Deandreis, D.; Pentlow, K.S.; Zanzonico, P.B.; Haque, S.; Gavane, S.; et al. Selumetinib-enhanced radioiodine uptake in advanced thyroid cancer. N. Engl. J. Med. 2013, 368, 623-632. [CrossRef]

101. Kessler, B.E.; Sharma, V.; Zhou, Q.; Jing, X.; Pike, L.A.; Kerege, A.A.; Sams, S.B.; Schweppe, R.E. Fak expression, not kinase activity, is a key mediator of thyroid tumorigenesis and protumorigenic processes. Mol. Cancer Res. 2016, 14, 869-882. [CrossRef] 
102. Tai, Y.L.; Chen, L.C.; Shen, T.L. Emerging roles of focal adhesion kinase in cancer. Biomed. Res. Int. 2015, 2015, 690690. [CrossRef] [PubMed]

103. Owens, L.V.; Xu, L.; Dent, G.A.; Yang, X.; Sturge, G.C.; Craven, R.J.; Cance, W.G. Focal adhesion kinase as a marker of invasive potential in differentiated human thyroid cancer. Ann. Surg. Oncol. 1996, 3, 6. [CrossRef]

104. Kim, S.J.; Park, J.W.; Yoon, J.S.; Mok, J.O.; Kim, Y.J.; Park, H.K.; Kim, C.H.; Byun, D.W.; Lee, Y.J.; Jin, S.Y.; et al. Increased expression of focal adhesion kinase in thyroid cancer: Immunohistochemical study. J. Korean Medi. Sci. 2004, 19, 710-715. [CrossRef] [PubMed]

105. Vella, V.; Pandini, G.; Sciacca, L.; Mineo, R.; Vigneri, R.; Pezzino, V.; Belfiore, A. A novel autocrine loop involving igf-ii and the insulin receptor isoform-a stimulates growth of thyroid cancer. J. Clin. Endocrinol. Metab. 2002, 87, 245-254. [CrossRef] [PubMed]

106. Lopez, J.S.; Banerji, U. Combine and conquer: Challenges for targeted therapy combinations in early phase trials. Nat. Rev. Clin. Oncol. 2017, 14, 57-66. [CrossRef]

107. Pirosa, M.C.; Leotta, S.; Cupri, A.; Stella, S.; Martino, E.A.; Scalise, L.; Sapienza, G.; Calafiore, V.; Mauro, E.; Spadaro, A.; et al. Long-term molecular remission achieved by antibody anti-cd22 and ponatinib in a patient affected by $\mathrm{ph}^{\prime}+$ acute lymphoblastic leukemia relapsed after second allogeneic hematopoietic stem cell transplantation: A case report. Chemotherapy 2018, 63, 220-224. [CrossRef]

108. Tirro, E.; Massimino, M.; Romano, C.; Pennisi, M.S.; Stella, S.; Vitale, S.R.; Fidilio, A.; Manzella, L.; Parrinello, N.L.; Stagno, F.; et al. Chk1 inhibition restores inotuzumab ozogamicin citotoxicity in cd22-positive cells expressing mutant p53. Front. Oncol. 2019, 9, 57. [CrossRef]

109. Ghosh, D.; Nandi, S.; Bhattacharjee, S. Combination therapy to checkmate glioblastoma: Clinical challenges and advances. Clin. Transl. Med. 2018, 7, 33. [CrossRef]

110. Zanardi, E.; Bregni, G.; de Braud, F.; Di Cosimo, S. Better together: Targeted combination therapies in breast cancer. Semin. Oncol. 2015, 42, 887-895. [CrossRef]

(C) 2019 by the authors. Licensee MDPI, Basel, Switzerland. This article is an open access article distributed under the terms and conditions of the Creative Commons Attribution (CC BY) license (http://creativecommons.org/licenses/by/4.0/). 